\title{
POTENSI BAKTERI LAUT SEBAGAI SUMBER ANTIBIOTIK BARU PENGHAMBAT SACCHAROMYCES AUREUS
}

\section{Marine Bacteria Potential as New Antibiotic Inhibit Saccharomyces aureus}

\author{
Nur Agustin Mardiana ${ }^{1 *}$, Tutik Murniasih ${ }^{2}$, Widya Dwi Rukmi ${ }^{1}$, dan Joni Kusnadi ${ }^{1}$ \\ ${ }^{1}$ Jurusan Teknologi Hasil Pertanian - Fakultas Teknologi Pertanian -Universitas Brawijaya \\ Jl.Veteran - Malang 65145 \\ ${ }^{2}$ Lembaga Pusat Penelitian Oseanografi \\ Jl. Pasir putih No. 1 Ancol Timur - Jakarta 14430 \\ *Penulis Korespondensi, email : nuragustin77@gmail.com
}

Disubmit: 1 September 2019 Direvisi: 27 Januari 2020 Diterima: 10 Februari 202

\begin{abstract}
ABSTRAK
Penemuan akan antibiotik baru yang semakin menurun dan meningkatnya penyakit yang disebabkan oleh Saccharomyces aureus telah meningkatkan minat terhadap bakteri laut sebagai produsen senyawa antibiotik baru. Tujuan dari penelitian ini adalah mengetahui aktivitas antibakteri dari lima isolat bakteri laut terhadap Saccharomyces aureus dan mengidentifikasi jenis bakteri laut yang memiliki aktivitas antibakteri tertinggi dengan 16S rRNA. Hasil penelitian menunjukkan dari lima isolat bakteri laut, isolat M1.SP3121015.101.a menunjukkan aktivitas antibakteri tertinggi dengan rerata daya hambat sebesar 10,20 $\mathrm{mm}$. Karakterisasi M1.SP3.121015.101.a dilakukan dengan menggunakan 16S rRNA didapatkan cluster gen pada \pm 1500 bp. Berdasarkan sekuens isolat M1.SP3121015.101.a memiliki kemiripan dengan Bacillus tequilensis strain K2.4.2 dengan 100\% kesamaan. Penelitian ini memberikan manfaat yaitu didapatkannya isolat bakteri laut yang memiliki kemampuan sebagai antibakteri dan dapat digunakan pada penelitian selanjutnya seperti proses isolasi senyawa bioaktif maupun proses optimasi.
\end{abstract}

Kata Kunci: 16S rRNA; Aktivitas Antibakteri; Bakteri Laut; Saccharomyces aureus

\begin{abstract}
A decreasing invention on new antibiotic and increasing disease caused by Saccharomyces aureus has raised increasing interest in marine bacteria as promising producers of new antibiotic agent. The aim of this study is to explore marine bacteria activity to inhibit Saccharomyces aureus. The result showed that among five isolates of marine bacteria, the M1.SP3121015.101.a strain showed the highest antibacterial activity with inhibition zone was 10,20 mm. The characterization ofM1.SP3.121015.101.a was carried out using $16 \mathrm{~S}$ $r R N A$, it showed that gene cluster at $\pm 1500 \mathrm{bp}$. The sequences of M1.SP3121015.101.a have been closes to Bacillus tequilensis strain K 2.4 .2 with 100\% similarity. This study provides some information about the isolate of marine bacteria that has the highest antibacterial activity and it can be used in further research such as the process of isolation of bioactive compounds and the optimization process.
\end{abstract}

Keywords: 16 S rRNA; Antibacterial Activity; Marine Bacteria; Saccharomyces aureus 


\section{PENDAHULUAN}

Penemuan akan antibiotik baru mengalami penurunan. Pada tahun 1960 dan 1970an ditemukan 4 kelas antibiotik, di akhir tahun 1980-an terdapat 2 kelas antibiotik, dan semenjak itu, belum ada penemuan tentang antibiotik baru (Urahn et al., 2016). Antibiotik yang ada saat ini, umumnya adalah turunan antibiotik yang ditemukan pada tahun 19601980 dan ditemukan kasus resistensi bakteri terhadap antibitiok yang mencapai $28 \%$ di kawasan Asia (Chen dan Huang, 2014). Salah satu bakteri yang mengalami resistensi terhadap antibiotik adalah Saccharomyces aureus .

Saccharomyces aureus adalah bakteri patogen yang menyebabkan penyakit infeksi dan food borne disease (Lin et al., 2016). Gejala yang timbul diakibatkan oleh bakteri Saccharomyces aureus yaitu abses, mastitis, plebitis, meningitis, infeksi saluran kemih, osteomielitis, dan toxic shock syndrome (Schaumburg et al, 2014). Setiap tahunnya terdapat 80.461 kasus di Amerika Serikat akibat resistensi $\mathrm{Sa}$ ccharomyces aureus (CDC, 2013). Untuk mengatasi resistensi Saccharomyces aureus, dibutuhkan sumber antibiotik baru. Salah satu sumber antibiotik berasal dari lautan.

Lautan memiliki banyak potensi karena menutupi $71 \%$ permukaan bumi dan $80 \%$ kehidupan di planet ini ditemukan di bawah permukaan laut (Kasanah dan Hamann, 2004). Lingkungan laut juga menyediakan keanekaragaman hayati bakteri yang luar biasa. Diperkirakan sekitar $10^{8}$ taksa bakteri berasal dari laut (Pedrós-Alió, 2006). Di lingkungan laut, bakteri berperan sebagai sumber makanan, sumber enzim, dan penghasil metabolit sekunder (Das et al., 2006)

Bakteri laut dapat menjadi sumber antibiotik baru yang menjanjikan karena menghasilkan senyawa unik daripada bakteri terestrial (Rey et al., 2004). Senyawa unik tersebut dihasilkan sebagai bentuk pertaha-nan diri dari kondisi ekstrem di lautan seperti tekanan tinggi, cahaya dan oksigen yang terbatas (De bbab et al., 2012). Bioaktif yang dihasilkan oleh bakteri laut seperti Halobacillin, Moja vensis A., dan Bogorol A (Mondol et al., 2013). Senyawa bioaktif tersebut memiliki aktivitas biologis seperti sebagai antibakteri, antitumor, antiviral, dan antifungi (Andryukov et al, 2019; Schinke et al., 2017).

Potensi yang dimiliki oleh bakteri laut cukup besar terutama di bidang bioteknologi dan farmasi. Beberapa studi tentang eksplorasi potensi bakteri laut sebagai antibakteri sudah pernah dilakukan oleh Judianti et al., (2014); Kasitowati et al., (2019); dan Tapilatu, (2016) di beberapa wilayah Indonesia. Namun, belum adanya studi tentang potensi bakteri laut yang diisolasi dari spons Lithistida di perairan Untung Jawa dan bakteri Laut Dalam Samudra Pasifik. Oleh karena itu, tujuan dari penelitian ini untuk meng-eksplorasi potensi bakteri laut tersebut se-bagai antibakteri dan mengidentifikasi jenis bakteri laut yang memiliki aktivitas antibak-teri terbesar dengan menggunakan 16S-rRNA. Penelitian ini memberikan manfaat yaitu didapatkannya isolat bakteri laut yang memi-liki kemampuan sebagai antibakteri dan dapat digunakan pada penelitian selanjutnya seperti proses isolasi senyawa bioaktif maupun proses optimasi.

\section{METODE}

Bahan yang digunakan dalam penelitian ini yaitu isolat M1.Sp3121015.101.a diisolasi dari spons Lithistida di Pulau Untung Jawa, Kepulauan Seribu, Jakarta. Isolat STA 45/ 18.11.16/1000 m/10-1.4, STA 50/24.11.16/25 m/10-1, STA 45/18.11.16/100 m/10-4. 2, dan STA $47 / 19.11 .16 / 5 \mathrm{~m} / 10-4$. (1.1) diisolasi dari laut dalam di Samudera Pasifik dan isolat Saccharomyces aureus diperoleh dari LIPI Oseanografi. Bahan lainnya yaitu media NA (Himedia), Muller Hinton Agar (Himedia), media M1 yang tersusun dari air laut, 0,4\% yeast ekstrak (Himedia), 0,2\% pepton (Himedia), dan $1 \%$ amilum (merck), media M2 yang tersusun dari air laut dan $0,375 \%$ marine broth (Carl roth), $\mathrm{NaCl}$ 0,9\% (Merck), standar 0,5 Mc Farland (Himedia), alkohol 96\% teknis, etil asetat teknis, akuades, tripton(himedia), protease (himedia), Quick-DNATM Fungal/ Bacterial Miniprep Kit (Zymo Research, D6005), MyTaq Red Mix (Bioline), Zymoclean Gel DNA Recovery Kit (Zymo Research), akuabides, DNA template, primer 27F $\mu \mathrm{l}$ sekuens AGAGTTTGATCMTGGCTCAG, dan primer 1492R $\mu$ l dengan sekuen TACGGYTA CCTTGTTACGACTT,

Alat yang digunakan pada penelitian ini yaitu Laminar air flow (Mascotte), inkubator (Binder), kompor listrik (Maspion), gelas ukur $100 \mathrm{ml}$ (Iwaki Pyrex), cawan petri plastik, timbangan digital (Scout Pro), kaca arloji, 
mikropipet (Thermo scientific), autoklaf (Tomy 8000), tip, bunsen, ose, bola hisap (D\&D), kuvet, tabung reaksi (Pyrex), corong (Herma), magnetic stirer (wisestir), sentrifuge (centri-fuge $5810 \mathrm{R}$ ), inkubator shaker (IKA KS 4000), dan labu ukur (Pyrex)

\section{Metodologi Penelitian}

Penelitian ini menggunakan Rancangan Acak Lengkap dengan dua kali ulangan untuk mengetahui kemampuan bakteri laut dalam menghambat Saccharomyces aureus. Setelah didapatkan isolat bakteri laut dengan kemampuan terbesar, maka akan dilakukan tahap identifikasi isolat tersebut dengan 165 rRNA.

\section{Fermentasi}

Masing-masing isolat bakteri laut diambil sebanyak 1 ose dan diinokulasikan ke dalam $30 \mathrm{ml}$ dan diinkubasi selama 72 jam suhu $30^{\circ} \mathrm{C}$ pada $150 \mathrm{rpm}$.

\section{Ekstraksi}

Isolat yang sudah difermentasi selama setelah 72 jam akan dilakukan ekstraksi. Ekstraksi dilakukan dengan etil asetat teknis (1: 1). Ekstrak digunakan untuk uji antibakteri terhadap Saccharomyces aureus .

\section{Uji antibakteri}

Uji antibakteri diukur dengan cakram difusi agar metode Kirby Bauer. Secara singkat, 1 ose Saccharomyces aureus dimasukkan ke dalam $0,9 \% \mathrm{NaCl}$. Kepadatannya dibandingkan dengan 0,5 Mc Farland $\left(1 \times 10^{8} \mathrm{cFu} / \mathrm{ml}\right)$. $100 \mu \mathrm{l}$ Saccharomyces aureus disebarkan pada MHA dan kertas disk ditempatkan pada MHA agar. $100 \mu \mathrm{g}$ ekstrak bakteri laut dilarutkan ke dalam $20 \mu \mathrm{l}$ metanol. Dikeringanginkan selama satu jam. Kemudian diinkubasi pada suhu $37^{\circ} \mathrm{C}$ selama 24 jam untuk menentukan zona bening. Zona bening menunjukkan penghambatan ekstrak terhadap Saccharomyces aureus .

\section{Identifikasi Bakteri Laut}

Identifikasi bakteri laut menggunakan $16 S$ rRNA. Proses identifikasi bakteri laut dimulai dari tahapan isolasi DNA bakteri. Untuk mengekstraksi DNA bakteri, $1,5 \mathrm{ml}$ sampel dimurnikan dengan Luria Bertani. Proses ekstraksi menggunakan ZR Fungal/ Bacterial DNA Kit.
Tahap selanjutnya yaitu amplifikasi. Proses amplifikasi PCR menggunakan MyTaq Red Mix. Proses PCR dilakukan dengan menggunakan volume $25 \mu \mathrm{l}$, ke dalam mikrotube $0,2 \mathrm{ml}$ bahan-bahan dimasukkan sebagai berikut: aquabides $9,5 \mu \mathrm{l}$, primer $27 \mathrm{~F} 1$ $\mu \mathrm{l}$, primer 1492R $1 \mu \mathrm{l}$, DNA tamplate $1 \mu \mathrm{l}$ dan master mix 12,5 $\mu$ l sehingga total volume adalah $25 \mu l$. Kemudian, mesin Thermal cycler dijalankan dengan pengaturan suhu sebagai berikut: denaturasi awal pada $95{ }^{\circ} \mathrm{C}$ selama 1 menit, denaturasi pada $95^{\circ} \mathrm{C}$ selama 15 detik, penempelan pada $52{ }^{\circ} \mathrm{C}$ selama 15 detik, ekstensi pada $68{ }^{\circ} \mathrm{C}$ selama 45 detik. Proses PCR dilakukan dalam 35 siklus.

Proses pemurnian hasil PCR menggunakan Zymoclean Gel DNA Recovery Kit. DNA yang dimurnikan dirun dengan elektroforesis pada gel agarosa 1,2\%. Ditambahkan $100 \mathrm{ml}$ Tris asetat EDTA (TAE) ke dalam elektroforesis sampai gel agarosa terendam. Kemudian disiapkan DNA marker dan dimasukkan ke dalam sumur dengan menggunakan mikropipet. Elektroforesis dijalankan dengan tegangan $70 \mathrm{~V}$ selama 25 menit. Selanjutnya, gel agarosa direndam dalam larutan etidium bromida (EtBr) selama 5 menit dan dibaca dengan transiluminator UV untuk mengamati pita yang terbentuk.

\section{Analisa Statistik}

Pengujian aktivitas antibakteri diuji dengan one way ANOVA dan uji lanjut dengan Tukey dengan selang kepercayaan sebesar 5\% di minitab 17. Proses alignment sequens menggunakan CLUSTAL W dengan bantuan aplikasi MEGA $X$ untuk pembuatan pohon filogeni.

\section{HASIL DAN PEMBAHASAN}

\section{Uji aktivitas Antibakteri}

Pengujian aktivitas antibakteri ekstrak dari isolat bakteri laut menggunakan difusi cakram. Metode difusi agar dilakukan dengan mengukur diameter zona bening (clear zone). Adanya diameter zona bening menunjukkan respon penghambatan pertumbuhan bakteri oleh suatu senyawa antibakteri. Syarat jumlah bakteri patogen untuk uji kepekaan/sensitiivitas yaitu $10^{5}-10^{8} \mathrm{CFU} / \mathrm{mL}$ (Her-mawan et al., 2007). Pada penelitian ini, meng-gunakan standar Mc Farland 0,5 yang setara dengan 1 x $10^{8} \mathrm{CFU} / \mathrm{ml}$ (Reverdy et al., 2001). 
Jurnal Teknologi Pertanian Vol. 21 No. 1 [April 2020] 49-56

Potensi Bakteri Laut sebagai Antibiotik Baru Pnghambat Saccharomyces Aureus [Mardiana dkk]

Tabel 1. Aktivitas antibakteri ekstrak beberapa isolat bakteri laut

\begin{tabular}{lc}
\hline Ekstrak Etil Asetat Isolat Bakteri Laut & Rerata Diameter Daya Hambat $(\mathbf{m m})$ \\
\hline M1. SP3.121015.101.a & $10,20 \pm 0,07 \mathrm{a}$ \\
STA45/18.11.16/1000 m/ $10^{-1} .4$ & $9,76 \pm 0,12 \mathrm{a}$ \\
STA50 /24. 11.16/25 m/10 $/ 10^{-1} \cdot 4$ & $7,72 \pm 0,25 \mathrm{bc}$ \\
STA45/ 18.11.16/100 m/ $10^{-4} .2$ & $8,18 \pm 0,19 \mathrm{~b}$ \\
STA47/19.11.16/ $5 \mathrm{~m} / 10^{-4} \cdot(1.1)$ & $7,19 \pm 0,09 \mathrm{c}$ \\
\hline
\end{tabular}

Keterangan: angka yang didampingi huruf yang sama dalam satu kolom menunjukkan hasil yang tidak berbeda nyata $(\mathrm{p}<0,05)$

Hasil analisa ragam dengan menggunakan one-way ANOVA menunjukkan bahwa terdapat perbedaan yang nyata aktivitas antibakteri ekstrak beberapa isolat bakteri laut, dapat dilihat pada Tabel 1.

Berdasarkan hasil penelitian menunjukkan bahwa isolat M1.SP3.121015.101.a mempunyai aktivitas antibakteri terbesar daripada isolat lainnya. Isolat M1.SP3.121015. 101.a adalah bakteri yang diisolasi dari sponge Listhistida sedangkan keempat isolat lainnya diisolasi dari sedimen dengan kedalaman laut yang berbeda. Kemampuan dari isolat M1.SP3.121015.101.a yang diisolasi dari sponge untuk menghambat Saccharomyces aureus didukung oleh penelitian Santos et al. Penelitian Santos et al. (2010), menunjukkan kemampuan hambat bakteri yang berasosiasi dengan sponge terhadap Saccharomyces aureus, Saccharomyces epidermis, Entrococcus faecium, dan Clostrodium fimi.

Berdasarkan zona hambat, Prijatmoko et al., (2018) menggolongkan kemampuan aktivitas antibakteri menjadi 4 yaitu lemah, sedang, kuat, dan sangat kuat. Aktivitas antibakteri dikatakan lemah jika diameter zona hambat sebesar $<8 \mathrm{~mm}$, sedang yaitu 8-14 $\mathrm{mm}$, kuat sebesar 15-19 mm, dan sangat kuat sebesar $>20 \mathrm{~mm}$. Aktivitas antibakteri dari isolat STA50/24.11.16/25m/10-1.4 dan STA47 $/ 19.11 .16 / 5 \mathrm{~m} / 10^{-4} .(1.1)$ tergolong ke dalam lemah. Aktivitas antibakteri STA45/18.11.16/ $100 \mathrm{~m} / 10^{-4} .2$, STA45/18.11.16/1000 m/10-1.4, dan M1. SP3.121015.101.a termasuk ke dalam sedang.

Biasanya bakteri yang bersimbiosis dengan makhluk hidup laut seperti sponge, menghasilkan metabolit sekunder 5-10 kali lebih banyak daripada bakteri yang hidup bebas (Long dan Azam, 2001). Bakteri yang bersimbiosis dengan sponge umumnya menghasilkan senyawa metabolit sekunder seperti terpenoid, alkaloid, peptida, dan poliketida (Taylor et al., 2007) Metabolit sekunder bia- sanya disekresikan oleh bakteri sebagai perlindungan diri melawan bakteri lainnya (Tyc et al., 2017). Selain itu, bakteri yang bersimbiosis dengan sponge biasanya menghasilkan enzim hidrolisis ekstraseluler yang digunakan untuk memetabolisme senyawa organik kompleks. Hal ini yang kemungkinan menyebabkan aktivitas penghambatan isolat M1.SP3121015.101.a lebih besar daripada isolat STA yang diisolasi dari sedimen laut.

\section{Identifikasi Bakteri Laut}

Identifikasi dengan 16S rRNA dilakukan terhadap bakteri laut yang memiliki aktivitas antibakteri terbesar terhadap Saccharomyces aureus. Di penelitian ini, isolat M1.SP3.121015. 101.a akan diidentifikasi jenisnya. Proses identifikasi dimulai dengan tahapan isolasi DNA, amplifikasi amplikon gen 16S rRNA dengan PCR, sekuensing, dan pembuatan pohon filogeni.

\section{Isolasi DNA}

Isolasi DNA menggunakan ZR fungal/ Bacterial DNA Kit. Hasil isolasi DNA dapat dilihat pada Tabel 2.

Tabel 2. Kuantifikasi DNA

\begin{tabular}{cccc}
\hline Isolat & $\begin{array}{c}\text { Konsentrasi } \\
(\mathrm{ng} / \mu \mathrm{l})\end{array}$ & $\begin{array}{c}\mathrm{A} \\
(260 / \\
280)\end{array}$ & $\begin{array}{c}\mathrm{A} \\
(260 / \\
230)\end{array}$ \\
\hline M1.SP3.12 & 557,5 & 2,01 & 2,02 \\
1015.101.a & & & \\
\hline
\end{tabular}

Keterangan: $\mathrm{A}=$ Absorbansi

Berdasarkan Tabel 2, isolat M1.SP3.12101 5.101.a mempunyai konsentrasi sebesar $557,5 \mathrm{ng} / \mu \mathrm{l}$ dengan nilai absorbansi rasio 260/280 sebesar 2,01. Absorbansi $260 \mathrm{~nm}$ digunakan untuk mengukur asam nukleat sedangkan absobansi pada $280 \mathrm{~nm}$ digunakan untuk mengukur gugus fenol dan rantai asam aromatik seperti triptofan, fenilalanin,tirosin, dan histidin. 
Rasio absorbansi pada 260 dan $280 \mathrm{~nm}$ digunakan untuk menguji kemurniaan DNA. Rasio 260/280 dianggap murni jika nilai absorbansi diantara 1,8-2,00 (Usman et al., 2014). Berdasarkan hasil pengukuran, nilai kemurniaan $>2$ menunjukkan adanya kontaminasi RNA.

Nilai absorbansi rasio $260 / 230$ yang didapat adalah 2,02. Rasio 260/230 digunakan sebagai indikator adanya kontaminan organik seperti fenol, trizol, garam buffer, ataupun senyawa organik lainnya. Jika nilai rasio 260/230 diantara rentang 2,0 dan 2,2, maka dianggap bebas dari kontaminan (LucenaAguilar et al., 2016).

\section{Amplifikasi}

Amplifikasi menggunakan PCR bertujuan untuk memperbanyak fragmen DNA yang sudah diisolasi. Hasil amplifikasi dapat dideteksi dengan elektroforesis. Hasil elektroforesis dapat dilihat pada Gambar 1.

Berdasarkan Gambar 1 dapat dilihat amplikon yang diampilifikasi menggunakan primer 27F dan 1492R merupakan gen $16 \mathrm{~S}-$ rDNA yang memiliki ukuran sekitar $\pm 1500 \mathrm{bp}$. Hal ini sudah sesuai dengan penelitian yang dilakukan oleh Akhmaloka dkk, (2006) dan Awad et al., (2015) penggunaan primer 27F dan 1492 R akan menghasilkan 1500 bp. Pita amplikon yang dihasilkan pada PCR terlihat tebal dan tidak smearing. Proses amplifikasi PCR yang dilakukan dianggap berjalan dengan baik. Irmawati (2013) menyatakan bahwa pita DNA yang tebal menunjukkan konsentrasi DNA yang tinggi sedangkan pita yang mengumpul (tidak ter-sebar) menunjukkan DNA total yang dieks-trak utuh.

\section{Sekuensing}

Sekuen gen penyandi 16S rRNA isolat M1.SP3.121015.101.a yang didapat akan digunakan untuk mendesain pohon filogeni. Sekuen gen penyandi $16 S$ rRNA merupakan molekul yang sempurna karena memiliki daerah conserved (dipertahankan) dan fungsi yang konstan pada tiap organisme, tersebar secara universal, dan mempunyai urutan sekuen yang terkonservasi dengan baik diantara anggota filogenetik yang luas (Madigan et al., 2015).

Primer 27F dan 1492R digunakan untuk proses sekuensing basa nukleotida. Proses sekuensing dengan kedua primer akan menghasilkan urutan basa nukleotida secara menyeluruh. Sekuens dari isolat M1.SP3.1210 15.101.a dapat dilihat pada Gambar 2.

Hasil sekuen gen penyandi $16 \mathrm{~S}$ rRNA dari isolat M1.SP3.121015.101.a dilacak homologinya terhadap sekuen 16S rRNA milik bakteri lainnya yang ada di dalam GenBank melalui program BLAST di NCBI. Dari BLAST di NCBI, didapatkan beberapa isolat bakteri yang memiliki kemiripan sekuens dengan isolat M1.SP3.121015.101.a. Isolat tersebut akan dibuat pohon filogeni untuk mengetahui hubungan kekerabatannya. Pohon filogeni dapat dilihat pada Gambar 3.

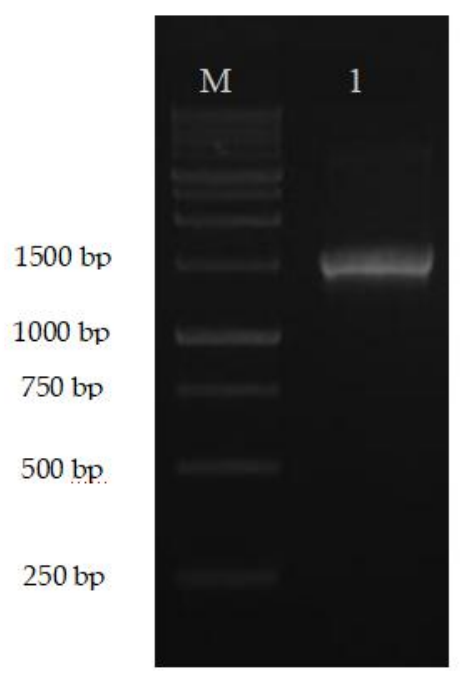

Gambar 1. Elektroforesis hasil amplifikasi gen 16S rRNA menggunakan PCR. Lajur M merupakan pita DNA ladder dan Lajur 1 merupakan pita amplikon 16S rRNA isolat M1.SP3.121015.101.a. 


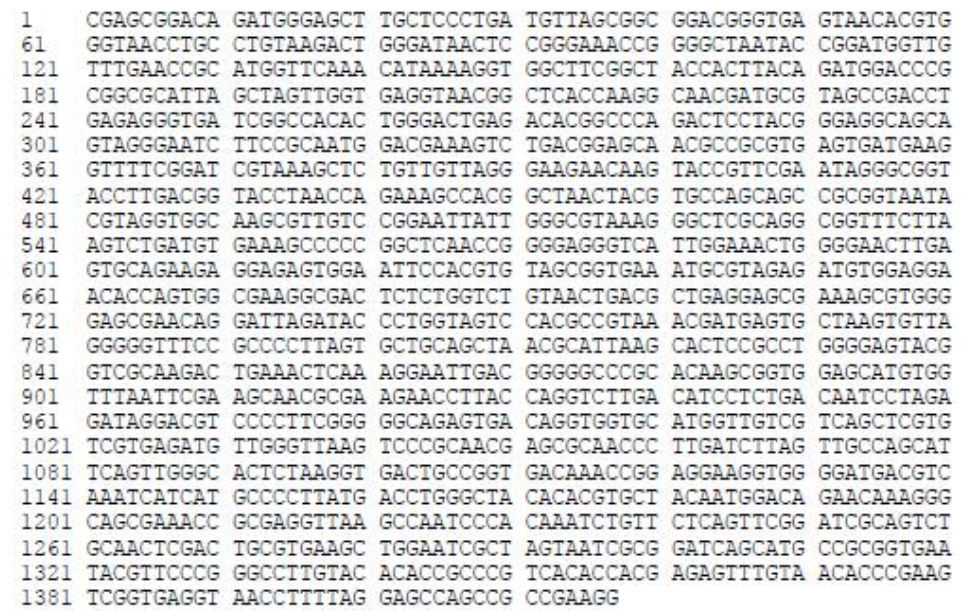

Gambar 2. Sekuens Gen Penyandi 16S rRNA isolat M1.SP3.121015.101.a

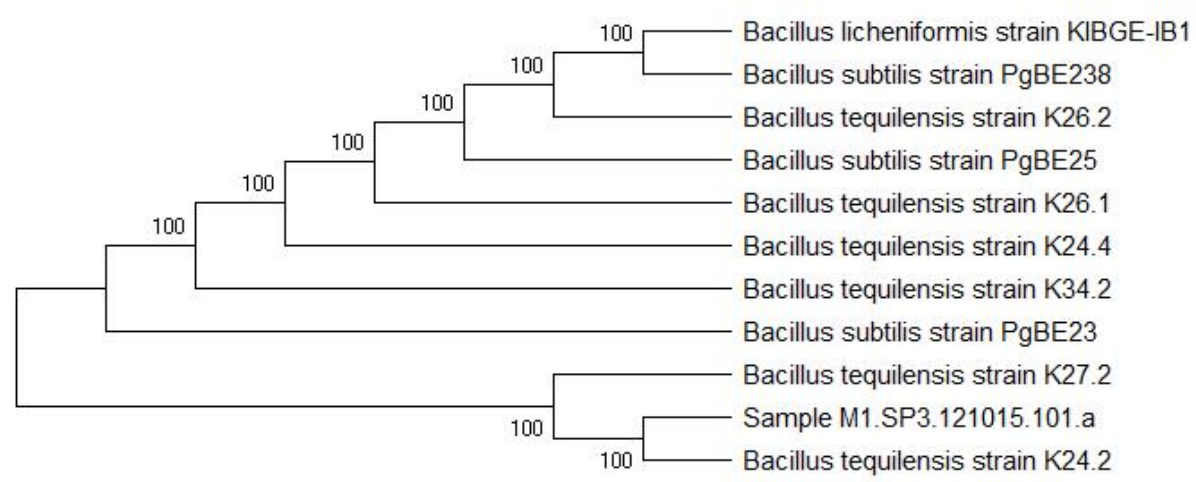

Gambar 3 Pohon Filogeni yang menunjukkan kekerabatan isolat M1.SP3.121015.101.a dengan beberapa spesies bakteri lainnya

Dari pohon filogeni yang terbentuk, Bacillus subtilis dan Bacillus tequilensis memiliki hubungan kekerabatan yang dekat. Penelitian yang dilakukan Gatson et al., (2006), mengidentifikasi Bacillus tequilensis sebagai $B$. subtilis dengan menggunakan metode biokimia dan analisis sekuensing dengan menggunakan 16S rRNA Bacillus subtilis menunjukkan 99\% kesamaan dengan Bacillus tequilensis. Pohon filogeni juga menunjukkan hubungan antara Bacillussubtilis dengan Bacillus licheniformis. Bacilluslicheniformis memiliki hubungan kekerabatan dekat dengan Bacillussubtilis berdasarkan analisa sekuensing $16 S$ rRNA dan 16S-23S internal transcribed spacer (Xu dan Côté, 2003). Diper-kirakan 80\% sekuens genome $B$. licheniformis mengandung gen ortolog dari B. subtilis (Rey et al., 2004).

Berdasarkan pohon filogeni, sampel M1.SP3.121015.101.a memiliki kekerabatan dekat dengan Bacillus tequilensis strain K24.2 yang ditunjukkan dengan cabang yang sama. Keberadaan dua isolat pada cabang yang sama menunjukkan kesamaan spesies (Ludwig dan Klenk, 2012). Isolat M1.SP3.1210 15.101.a memiliki persentase homologi sekuens 16S rRNA mencapai 100\%. Oleh karena itu, isolat M1.SP3.121015.101.a dianggap mempunyai kesamaan spesies dengan Bacillus tequilensis strain K 24.2.

\section{SIMPULAN}

Isolat M1.SP3.121015.101.a memiliki potensi yang cukup besar untuk digunakan sebagai sumber antibiotik baru. Hal ini dikarenakan isolat M1.SP3.121015.101.a memiliki kemampuan penghambatan terbesar terhadap Saccharomyces aureus dengan diameter daya hambat sebesar 10,20 mm. Isolat M1.SP3.1210 15.101.a memiliki kekerabatan dekat dengan strain Bacillus tequilensis K.24.2 dengan 
persentase kesamaannya yaitu $100 \%$. Penelitian ini diharapkan dapat memberikan kontribusi dalam bidang bioteknologi dan farmasi dari adanya informasi aktivitas antibakteri isolat bakteri laut dan dapat digunakan pada penelitian selanjutnya seperti proses isolasi senyawa bioaktif maupun proses optimasi.

\section{UCAPAN TERIMA KASIH}

Terima kasih kepada LIPI Oseanografi yang telah mendukung dan mendanai penelitian ini.

\section{DAFTAR PUSTAKA}

Akhmaloka, -A. Suharto, -S. Nurbaiti, -I.N. Tika, -F.M. Warganegara. 2006. Ribotpying identification of thermophilic bacterium from papandayan crater. ITB Journal of Engineering Science. 38(1), 1-10. https://doi.org/10.5614/itbj.eng.sci.200 6.38.1.1.

Andryukov, -B., Mikhailov, -V., Besednova, N. .2019. The biotechnological potential of secondary metabolites from marine bacteria. Journal of Marine Science and Engineering. 7(6), 1-16. https://doi.org/ 10.3390/jmse7060176.

Awad, G. E. A. Mustofa -H., Danial E., Abdelwahed, -N.A.M, Awad H. (2015) 'Enhanced production of thermostable lipase from Bacillus cereus ASSCRC-P1 in waste frying oil based medium using statistical experimental design', Journal of Applied Pharmaceutical Science, 5(9), pp. 007-015. doi: 10.7324/JAPS.2015.50902.

Chen, -C.J., Huang, Y.C. 2014. New epidemiology of Staphylococcus aureus infection in Asia. (Themed Section: New epidemiology of Staphylococcus aureus infections.). Clinical Microbiology and Infection. 20(7), 605-623. https:/ / doi.org /10.1111/1469-691.12705

Das, -S., Lyla, -P.S. Khan, -S.A. 2006. Marine microbial diversity and ecology: Importance and future perspectives. Current Science. 90(10), 1325-1335. https://pdfs. semanticscholar.org/074a/cc7188e76135 9d05c98855cb1453f84c55fb.pdf

Debbab, -A., Aly -A.H, Ruangelie -E.E, Victor -W. 2012. New anthracene derivatives -
Structure elucidation and antimicrobial activity. European Journal of Organic Chemistry. 7, 1351-1359. https://doi.org /10.1002/ejoc.201101442.

Gatson -JW., Benz -B.F., Chandrasekaran C., Satomi -M., Venkateswaran -K., Hart -ME. 2006. Bacillus tequilensis sp. nov., isolated from a 2000-year-old Mexican shaft-tomb, is closely related to Bacillus subtilis. International Journal of Systematic and Evolutionary Microbiology. 56(7), 1475-1484. https:// doi.org/10.1099/ijs.0. 63946-0.

Irmawati.. 2013. Perubahan keragaman genetik ikan kerapu tikus (cromileptes altivelis) generasi pertama pada stok hatchery. IPB. Bogor. https:/ / repository. ipb.ac.id / handle/123456789/6996.

Judianti, -O.W.D. -M.M Fiqri, -M.K. Ansyori, G. Trimulyono. 2014. Aktivitas antibakteri isolat bakteri yang berasosiasi dengan spons demospongiae dari Pantai Paciran Lamongan. Sains \& Matematika. 2(2), 49-53. https://journal.unesa.ac.id/ index.php/sainsmatematika/article/vie $\mathrm{w} / 44$

Kasanah, -N. Hamann, -M.T. 2004. Development of antibiotics and the future of marine microorganisms to stem the tide of antibiotic resistance.', Current opinion in investigational drugs (London, England: 2000). 5(8), 827-37. http://www.ncbi.nlm.nih.gov/pubmed /15600239\%0Ahttp://www.pubmedcen tral.nih.gov/articlerender.fcgi?artid=PM C4969015.

Kasitowati, -R.D. -K Wittriansyah, A Trianto4, -D.C., Pratiwi, -M.AP Panjaitan. 2019. Antifungal activity of marine sponges (Class Demospongiae) collected from Biak, Indonesia. IOP Conference Series: Earth and Environmental Science, 236(1), 0-7. https:// doi.org/10.1088/17 55-1315/236/1/012102.

Lin, -J., Lin -D., Xu -P., Zhang -T., Ou -Q., Bai -C., Yao -Z. 2016. Non-hospital environment contamination with Staphylococcus aureus and methicillin-resistant Staphylococcus aureus: proportion metaanalysis and features of antibiotic resistance and molecular genetics, Environmental Research, 150, pp. 528-540. doi: 10.1016/j.envres.2016.06.040.

Long, -R., Azam, -F. 2001. Antagonistic 
interactions among marine planktonic bacteria. Applied and Environmental Microbiology. 67(11), 4975-4983. https:/ / doi.org/ 10.1128/AEM.67.11.4975.

Lucena-Aguilar -G., Sánchez-López -AM., Barberán-Aceituno -C., Carrillo-Ávila JA., López-Guerrero -JA., AguilarQuesada -R. 2016. DNA source selection for downstream applications based on dna quality indicators analysis. Biopreservation and Biobanking. 14(4), 264270. https://doi.org/ 10.1089/bio.2015.0 064.

Ludwig, -W., Klenk, -H.P. 2012. Overview: a phylogenetic backbone and taxonomic framework for procaryotic systematics. Bergey's Manual ${ }^{\circ}$ of Systematic Bacteriology. 49-65. https:// doi.org/ 10.1007/ 978-0-387-21609-6_8.

Madigan, -M.T., Martinko, -J.M., Parker, -J. 2015. Brock biology of micro-organisms. Pearson

Mondol, -M.A.M., Shin, -H.J. Islam, -M. T. .2013. Diversity of secondary metabolites from marine bacillus species: chemistry and biological activity', Marine Drugs, 11(8), 2846-2872.https:/ / doi.org/10.3390/md11082846.

Pedrós-Alió, C. (2006) 'Marine microbial diversity: can it be determined?', Trends in Microbiology, 14(6), pp. 257-263. doi: 10.1016/j.tim.2006.04.007.

Prijatmoko, D., Syafira, N. L. and Lestari, P. E. (2018) 'Antibacterial activity of essential oil extracts from Curcuma xanthorrhiza roxb. rhizomes against bacteria causing pulp necrosis. Journal of Dentomaxillofacial Science. 3(3), 144. https:/ / doi.org /10.15562/jdmfs.v3i3.763.

Rey, -M. W. et al. (2004) 'Complete genome sequence of the industrial bacterium Bacillus licheniformis and comparisons with closely related Bacillus species.', Genome biology, 5(10). doi: 10.1186/gb2004-5-10-r77.

Santos -OC., Pontes -PV., Santos -J.F., Muricy -G., Giambiagi-Demarval -M., Laport MS. 2010. Isolation, characterization and phylogeny of sponge-associated bacteria with antimicrobial activities from Brazil', Research in Microbiology. Elsevier Masson SAS. 161(7), 604-612. https://doi.org 10.1016/j.resmic.2010.05.013.

Schaumburg -F., Alabi -A.S., Peters -
G., Becker -K. 2014. New epidemiology of Staphylococcus aureus infection in Africa. Clinical Microbiology and Infection. European Society of Clinical Infectious Diseases. 20(7), 589-596. https:// doi.org /10.1111/1469-0691.12690.

Schinke, -C., Thamires -M., Sonia -C.N., Itamar -S.M., Felix -G.R. 2017. Antibacterial compounds from marine bacteria, 2010-2015. Journal of Natural Products. 80(4), 1215-1228. https:/ / doi. org 10.1021/acs.jnatprod.6b00235

Tapilatu, -Y.H. 2016. Marine Bacteria from eastern indonesia waters and their potential use in biotechnology. OmniAkuatika. 12(1). https://doi.org/10.2088 4/1.oa.2016.12.1.32.

Taylor, -M.W. Radax -R, Steger -D, Wagner M.. 2007. Sponge-associated microorganisms: evolution, ecology, and biotechnological potential. Microbiology and Molecular Biology Reviews. 71(2), 295-347. https:// doi.org/10.1128/mmbr.0004006

Tyc, -O., Song -C., Dickschat -J.S,. Vos M, Garbeva -P. 2017. The ecological role of volatile and soluble secondary metabolites produced by soil bacteria. Trends in Microbiology. Elsevier Ltd. 25(4), 280292. doi: 10.1016/j.tim.2016.12.002

Urahn, -S.K., Allan -C., Ellizabeth -J. 2016. A Scientific Roadmap for Antibiotic Discovery. The Pew Charitable Trusts, (May), 1-42. http://www.pewtrusts. .org/en/research-and-analysis/reports/ 2016/05/a-scientific-roadmap-for-antibi otic-discovery

Usman, -T., Yu -Y., Liu -C., Fan -Z., Wang -Y. 2014. Comparison of methods for high quantity and quality genomic DNA extraction from raw cow milk. Genetics and Molecular Research. 13(2), 3319-3328. https://doi.org/10.4238/2014.April.29.1 0

Xu, -D., Côté, -J.C. 2003. Phylogenetic relationships between Bacillus species and related genera inferred from comparison of $3^{\prime}$ end 165 rDNA and $5^{\prime}$ end 16S-23S ITS nucleotide sequences', International Journal of Systematic and Evolutionary Microbiology. 53(3), 695-704. doi: 10.1099/ijs.0.02346-0. 